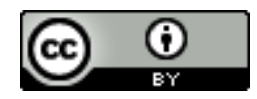

Esta obra está sob o direito de Licença Creative Commons Atribuição 4.0 Internacional.

\title{
SÂNSCRITO: BASE PARA OS ESTUDOS LINGUIISTICOS COMPARATIVOS E GRAMATICAIS
}

\author{
Joselito Araújo Silva ${ }^{1}$ \\ Luciane Victorino Barbosa ${ }^{2}$ \\ Aline Pereira do Nascimento Costa ${ }^{3}$ \\ José Petrúcio dos Santos Filho ${ }^{4}$ \\ José Glicerió Augusto Canuto ${ }^{5}$ \\ Edivânia Maria Silva de Lima 6
}

\section{RESUMO}

Língua de tradição sagrada hindu no passado, o Sânscrito se transformou no principal elo de ligação das línguas mais antigas da humanidade, particularmente da Europa. Essa pesquisa tem como objetivo apresentar as contribuições que o Sânscrito trouxe para os estudos linguísticos e que exercem influências na linguagem até os dias de hoje. Problematiza sua importância para a melhor compreensão dos estudos de linguística e de gramática. A metodologia aplicada nessa pesquisa é teórica e bibliográfica, feita num estudo comparativo de textos bem pertinentes. Este artigo revela como resultados a ilação de que o Sânscrito pode ser considerado como a base dos estudos linguísticos e gramaticais e convida o professor de Linguagens a conhecer essa base.

Palavras-chave: Sânscrito, Indo-europeu, estudos comparativos, linguística.

\footnotetext{
1 joselitoaraujo947@gmail.com

2 lucianebarbosa06@hotmail.com

3 aline.prof.alpi@hotmail.com

${ }^{4}$ pettrucio@yahoo.com.br

5 gliceriocanuto5@gmail.com

6 edivania201210@hotmail.com
} 


\section{INTRODUÇÃO}

O século XVI se caracterizou por ser um século de expansão marítima. Época que as nações europeias saíram em busca de riquezas. Viajantes exploradores e religiosos ancoraram na Índia. Lá se encantaram com a cultura e mistérios da Índia. País rico em línguas e dialetos. Uma dessas línguas encontradas pelos europeus foi o Sânscrito.

Uma das riquezas encontradas pelos Europeus foram os Vedas. Os Vedas foram os primeiros textos indianos escritos em Sânscrito, os quais foram produzidos há mais de $\mathrm{V}$ mil anos a.C. e que constituíram um conjunto de textos sagrados da religião hindu. O Hinduísmo teve como fulcro de seus ritos sagrados o Sânscrito.

Religiosos como o missionário italiano Roberto Nobili, o missionário português São João de Brito, o missionário jesuíta alemão Johann Ernst Hanxleden não somente esses missionários, mas outros europeus que vieram em seguida também perceberam a afinidade. Os missionários conhecedores das línguas clássicas como o Grego e como o Latim perceberam semelhança entre essas línguas e o Sânscrito. No entanto não aprofundaram essa questão, pois o contexto histórico da Europa não favoreceu os confrontos de vocábulos dessas línguas. (BRANDÃO e VITORINO, 2015)
O estudo da comparação dos vocabulares só surgiu no século XVIII, quando Williams Jones apresentou na Real Sociedade Asiática de Calcutá, em 1786, uma análise dessa descoberta entre as línguas clássicas. O Sânscrito, como língua sagrada da Índia, em que a elite religiosa da época, a empregava em rituais de louvação a brāhmane possuía toda uma estrutura, a qual facilitou essa comparação. (ibidem)

Assim como se pode observar nestes exemplos das línguas grega, sânscrita e latina: a palavra cavalo, do latim equus, a palavra pai, do latim pater, a palavra mãe do latim mater, Deus, Deus do latim; mãe do grego méter; cavalo do grego íppos, Deus do gregoTheós, pai, do grego patér, que se origina do sânscrito pitá (raiz pâ proteger), o qual significa protetor da família, o que nutre e o que governa. Cavalo, do sânscrito áçvas. Mãe, do sânscrito mâtâ (raiz mâ medir), aquela que mede, que economiza, que distribue aos membros da família, para Franz Bopp ${ }^{i}$ significa a que gera, aquela que produz. Deus, do sânscrito Deva (raiz div resplandecer, brilhar), que por sua vez significa luz, o que brilha e que resplandece. (STELLA,1955, p,155)

$\mathrm{O}$ seu uso em rituais religiosos exigia um trabalho de refinamento e cuidado para que a língua não se "contaminasse" com expressões e vocábulos que viessem a "poluir" a "pureza" e a "beleza" da língua sagrada. 
Esse trabalho com a língua, no que diz respeito a pronúncia exata dos sons da língua, desenvolveu uma atividade da área que mais tarde seria chamada de fonética, além do estudo relacionada à gramática.

A originalidade de detalhes e de análise relacionada à Fonética e à Gramática transformaram os hindus nos primeiros e pioneiros nessas duas ciências. Eles se anteciparam antes mesmo até dos gregos (PETTER, 2001, p.11).

O Sânscrito, língua sagrada antiga do hinduísmo, falada pelos hindus no século V a. C., era composta de 4.000 "sutras" ou regras, as quais explicavam a gramática hindu. COSERIU (1973) chega afirmar que a língua Sânscrita é língua considerada perfeita, muita utilizada pela elite indiana. Foi veiculada em textos religiosos falados e escritos. A partir do século III a. C. não é mais empregada como língua da comunicação e das relações sociais. Seu uso ficou restrito à manifestação religiosa escrito (WEEDWOOD, 2002, p.14).

$\mathrm{O}$ primeiro documento escrito em Sânscrito, que se tem notícia, foi a gramática escrita por um gramático de nome Panini. Esse texto chamou atenção dos exploradores e religiosos europeus por sua descrição profunda, perfeita e avançada para a época. A obra de Panini se destaca por fazer um trabalho profundo, refinado e moderno do material fônico da língua, seus sons, articulações e as relações de significação. (IBIDEM)

As regras lógicas, sofisticadas transformaram a atividade hindu em um referencial teórico, que ainda hoje perdura e influencia a teoria da linguística contemporânea. Um dos teóricos europeus que sofreu influência dos estudos linguísticos da Índia foi Saussure, o qual era professor de Sânscrito.

PETTER (2010) afirma que os gramáticos hindus se dedicaram a descrever a língua sânscrita minuciosamente de tal maneira que ainda hoje é modelo para o mundo cientifico. $\mathrm{O}$ cuidado com a análise da língua por ser dedicado perfeição de trabalho. Por ser um trabalho de cunho religioso, de intenções religiosas, isso facilitou a preservação da originalidade da língua. Essa originalidade chamou a atenção dos viajantes religiosos, os quais encontraram muita semelhança da língua sagrada hindu, o Sânscrito, com o Latim, o Grego, o Germânico e o Eslavo. Essa semelhança fez com que deduzissem que havia uma língua comum a todas elas. 


\section{METODOLOGIA}

Trata-se de uma revisão de literatura tradicional, não sistemática, descritiva, de natureza qualitativa e bibliográfica, já que a

\section{A DESCOBERTA DO SÂNSCRITO PELOS JESUITAS}

$\mathrm{O}$ primeiro contato dos europeus com o sânscrito se deu por meio dos missionários. Esse contato impulsionou o surgimento dos estudos linguísticos comparativos das línguas indo-europeias. Muitos séculos depois, já no século XVI, o missionário italiano Roberto Nobili (15771656), no processo de conversão da casta superior da Índia, adotou hábitos e costumes dos sannyasi, o que o transformou em um exímio conhecedor do sânscrito e do tamil (TERRA, p, 52.2005).

Em seguida, um outro missionário, o português São João de Brito (1647-1693) utilizou o mesmo método desenvolvido por Nobili, no sudeste da Índia, no trabalho missionário na região de madura. Outros missionários europeus seguiram o mesmo percurso, sem, no entanto, aprofundar esta semelhança gramatical entre sânscrito, latim e grego, pois eles tinham pleno domínio dessas duas línguas clássicas. (VIARO, 2013, p. 26):

Essa afinidade entre as línguas não despertou nenhum interesse nos europeus, antes do século XVIII, na língua dos brâmanes. Foi neste século que o panorama análise se realizou em diversas fontes de pesquisas como conteúdo de livros, artigos científicos, sites, dissertações, teses e bibliográficas virtuais.

europeu se voltou para essa questão, quando os missionários deixaram de olhar a língua como uma atividade prática e religiosa e passaram-na a estudar com interesse científico. Os estudos dos missionários avançaram a tal ponto, que um jesuíta alemão criou obras sobre o sânscrito.

O missionário jesuíta alemão Johann Ernst Hanxleden (1681-1732), no ano de 1701 em missão religiosa em Malabar, na Índia, criou uma gramática de sânscrito e um dicionário de sânscrito e português. Esse trabalho fez com que outros trabalhos surgissem acerca do sânscrito. Assim, também, o carmelita Paulinus S. Bartolomeo, em missão também em Malabar, inspirando-se na obra de Hanxleden, lançou em Roma, em 1790, a primeira gramática de sânscrito no ocidente: Sidharubam seu Grammatica Sanscridamica (Roma,1790); que foi seguida pela obra: Viacara seu Locupletissima Sanscridamicae Linguae Institutio (TERRA,2010, p,52).

Além da gramática e do dicionário do sânscrito, Johann também escreveu algumas obras que mostrou a semelhança entre o sânscrito, língua sagrada dos hindus, e as línguas europeias: Dissertativo de 
Antiquitate et affinitate Linguae

Zendicae,Sanscridamicea et Germanicae (Pádua,1798); Dissertativo de Latini Sermonis origine et cum orientalibus linguis conexione (Romae, 1802).

Sabe-se que décadas antes de Hanxleden, um outro jesuíta, Calmette descobriu dois livros do Veda, os quais foram enviados a Paris, no ano de 1739, para Hamilton traduzi-los. Este prisioneiro de Napoleão, em 1802. (OPUS CITATUS)

Coeurdoux, jesuíta, escreveu vários artigos, os quais foram enviados a Academie des Inscriptions,em Paris, provando as semelhanças entre sânscrito, grego e latim. E lançou uma hipótese de que essas três línguas tiveram uma origem em comum. Esses estudos dos jesuítas ficaram esquecidos por quarenta anos.

A ocupação da Índia pela Inglaterra foi fundamental para os estudos linguísticos adquirem uma maior atenção dos ingleses, pois possibilitou o contato com o mundo hindu. O mundo cultural como as leis e os costumes desse povo. Assim foram obrigados a conhecer a língua, pois nela estavam escritos os códigos de leis, os livros sagrados e a sua literatura milenar. Dentre os ocupantes ingleses, estavam o juiz Sir William Jones, Charles Walkins, Henry Thomas Colebrook (TERRA, 2001, p 52).

\section{OS ESTUDOS HINDUS}

Os hindus estão na vanguarda no mundo nas prescrições dos estudos linguísticos. Não se conhece nenhum povo que tenha uma análise detalhada e profunda de uma língua. A Índia tem esse privilégio de ter esse estudo. Mas a preocupação com a língua como elemento fundamental nas relações sociais surgiu na Grécia com os filósofos: Platão e Aristóteles, os quais criaram as bases filosóficas da terminologia, também questionaram a relação entre nome e objeto, isto é, $a$ arbitrariedade do signo linguístico, de problemas semântico, filosóficos, não formal e morfológico (MASCUSCHI, 2008, p,26).

É a partir da Grécia Antiga que as ideias linguísticas começam a germinar, a discutir a língua na tradição do mundo ocidental, segundo Alonso-Cortês (1993, p.277, apud Jucelia, 2019, p, 25), “sin embargo, dada la influencia ejercida por la Gramática hindú en la tradición occidental desde el siglo pasado, aquélla ha pasado a formar parte del estudio de la tradición occidental". Com isso a Grécia se torna pioneira nos estudos gramaticais do ocidente.

Os hindus aos estudarem a língua sob uma perspectiva religiosa com a intenção de preservar os textos sagrados, livres dos falares populares e, não 
contaminarem a língua com expressões erradas. Desenvolveram um trabalho profundo morfossintático de refinamento dos sons da língua sânscrita. Para Petter (2003, p.18, apud Jucelia, p,25), objetivo era "assegurar a conservação literal dos textos sagrados e a pronúncia correta das preces [...] para defender-se da "invasão" dos falares populares". Os hindus se transformaram nos primeiros povos do mundo a ter uma gramática escrita, que se tem conhecimento.

Os estudos linguísticos remontam a 2.500 a. C. com o trabalho de Panini, autor da primeira gramática não-ocidental, segundo o linguista francês George Mounin, (1970, p,65) “É na Índia antiga que se encontra a provável primeira reflexão manifesta levada a cabo por homens sobre a sua linguagem e, sobretudo, a primeira descrição duma língua, como tal. E é espantosa a extraordinária qualidade logo alcançada por essa estreia no labor descritivo linguístico."

\section{ORIGEM DOS ESTUDOS GRAMATICAIS}

Os estudos da linguagem é um conhecimento antigo, mas uma ciência nova. Essa ciência se constituiu a partir da publicação dos trabalhos de Ferdinand de Saussure (1857-1913), no Curso de Linguística Geral (1916). Uma ciência não se constituí de forma aleatória, mas segue uma sequência de conhecimento até atingir um patamar de conhecimento que impulsiona a construção de um arcabouço teórico originando e se transformando numa ciência.

A Linguística Moderna se constituiu a partir da tradição hindu (Séculos V a IV a.C.), com os primeiros estudos gramaticais acerca da descrição da língua sânscrita. Com a origem dos estudos gramaticais na Grécia Antiga (Séc. V a.C.), os romanos contribuíram para a reflexão filosófica e a inovação linguística, como também os estudos medievais desenvolveram a reflexão filosófica, sem se deter na investigação.

$\mathrm{Na}$ Renascença, dois pontos de vista se opunham: grammatica speculativa $e$ grammatica positiva. Essas duas abordagens se caracterizavam como, particulares, a qual se detinha aos fenômenos físicos, com características biológicas na metodologia e nos resultados, e a abordagem "universal", trabalha com a língua, os seus elementos constituintes e tem como referência o método filosófico e da lógica (WEEDWOOD, 2002, p.68)

\section{A GRAMÁTICA DE PANINI}

Considera-se o trabalho de Panini (Séc. IV a.C.) de grande relevância para os estudos linguísticos no ocidente acerca, da classificação fisiológica dos sons e da estrutura das palavras do Sânscrito. Assim 
sendo,o trabalho do gramático hindu se reveste de grande para o mundo ocidental. Conforme Lyons (1979, p.20), “em dois pontos podemos considerar o trabalho linguístico hindu superior à gramática tradicional do ocidente: primeiro, na fonética, e segundo, no estudo da estrutura interna das palavras".

A primeira gramática que se tem notícia no mundo é a de Panini, gramático hindu, que analisou a estrutura do sânscrito de maneira profunda. Segundo Petter (2003), apesar de Panini ter estudado a língua numa perspectiva religiosa, todavia foram os gregos que abordaram a língua numa visão filosófica. (BENVENISTE,1989, p.30)

A gramática hindu possui em sua estrutura cerca de 4.000 regras. Segundo Alonso-Cortês (1993, p.277, apud Jucelia, 2019, p, 26).

A qual está basada en el concepto de regla y sustitución es ya de tipo generativo en la medida en que es una gramática explícita de reglas sometidas a un orden. Lo que se entiende por gramática de Panini es el $<<$ tratado en ocho libros $>>$ o astadhyayi que fue publicado por primera vez por el filólogo alemán Otto Bohtlingk en Bonn en 1839-40 con el título de Paninis Acht Bucher grammatischer regeln (Los ocho libros de reglas gramaticales de Panini).
As diferenças entre as articulações consonânticas surdas e sonoras e entre as nasais e as orais e entre aspiradas e nãoaspiradas são criações dos hindus tendo Panini como mentor e criador da primeira gramática. Além disso também desenvolveu uma análise da palavra em morfemas por conta da estrutura do Sânscrito, que permitiu essa abordagem. (CARBONI,2008, p,16)

A constituição geográfica da Grécia Antiga possibilitava as discussões acerca das ideias do espírito. Os aspectos semânticos, filosóficos, não formal, morfológico e a arbitrariedade do signo linguístico despertaram nos filósofos gregos a curiosidade de estudar a língua.

A importância do Sânscrito, língua sagrada da Índia, se compara à língua latina, língua do Império Romano, sendo ambas línguas de cultura e de relações sociais, "o Sânscrito é chamado de 'o latim da Índia', pois era ao mesmo tempo uma língua de cultura e de relação, dispersando-se por todo o território hindu, em diversos dialetos (CHASSOT, 2004, p.30)". Como línguas vivas, em sua época, sofreram dispersão e se transformaram em vários dialetos.

Martelotta (2011) afirma que os estudos linguísticos modernos tiveram início com os trabalhos linguísticos dos hindus sobre análise gramatical, que contribuíram com o surgimento das teorias linguísticas modernas. $\mathrm{O}$ contato dos 
europeus com o Sânscrito originou uma série de publicações de trabalhos científicos voltados para os estudos linguísticos como: gramática indo-europeia, a qual originou a Filologia comparativa e a Linguística histórica.

\section{OS GREGOS E OS ESTUDOS GRAMATICAIS}

A Grécia Antiga (séc. V a.C.) foi palco dos primeiros estudos linguísticos do mundo ocidental, pois foram os gregos que primeiro deram uma característica filosófica às análises linguísticas, diferentemente dos hindus de cunho religioso. A partir do trabalho dos gregos, os estudos gramaticais adquiriram um novo direcionamento com o surgimento da gramática como a: arte de ler e escrever, obra voltada para ler e escrever corretamente, isto é, Grammatiké.

No rastro da Grammatiké surgiram a escrita e a erudição grega em que:

Até a época de Platão e Aristóteles, inclusive, o vocábulo significava simplesmente aquele que entendia o uso das letras, grámmata, e que podia ler e escrever; [...] téchnè grammatiké era a arte de ler e escrever. [...] O termo grammatiké significava, de início, apenas a compreensão das letras; o que hoje se considera como investigação linguística estava compreendido sob o título genérico de philosophia, que cobria então um campo muito mais amplo do que o da "filosofia" de hoje, pois abrangia virtualmente todos os setores do conhecimento humano (ROBINS, 1983, p.10).

Para Lyons (1979), os gregos se detinham nos textos escritos, daí a origem do vocábulo "gramática", em que se aplica a arte de escrever. Além de Platão, com sua obra o Crátilo, em que trata da relação homem e linguagem (NEVES,198, p,46). Aristóteles não escreveu nenhuma gramática, mas contribuiu com o tratado gramatical no mundo ocidental ao tratar das categorias gramaticais Alonso-Cortês (1993, pp.282-284, apud Jucelia, 2019, p, 26),

Tratar de las categorías, y de las cuestiones de Retórica (Tékhne rhetoriké) y Lógica. [n] Aristóteles se ha ocupado de lo que es episteme, conocimiento universal, o de conocimiento técnico genérico como Física o Psicología. [n] Frente a la tékhne está la empiria o experiencia que es conocimiento de lo singular; pero la tékhne es universal genérico. [n] También el concepto tékhne engloba el hacer artesanal, como el de un zapatero, más próximo a la empiria, o el hacer de un pintor o escultor, por lo que se mantiene una ambigüedad entre tékhne como conocimiento universal-genérico (y causal) o como conocimiento singular $<<$ pues la experiencia hizo el arte/técnica $>>$. 
No que se refere à arte de escrever, não se restringe somente ao ato de aprender o estudo da gramática, mas abrange outras áreas como o estudo, a leitura e a interpretação dos poetas helênicos:

A gramática era considerada o instrumento para o aprendizado da variedade assumida como modelar. Não a gramática em si, tomada isoladamente, mas combinada com a leitura, o estudo e o comentário dos textos dos poetas e prosadores culturalmente prestigiados. (FARACO, 2017, p.12)

Durante o séc. V a.C., na Grécia Antiga, os gregos tinham os estudos linguísticos como um ramo da Filosofia. A língua era uma parte constitutiva dos questionamentos filosóficos acerca da natureza e da sociedade. Como já foi citado neste trabalho, como um conhecimento antigo o estudo da língua.

\section{WILLIAM JONES E UMA NOVA PERSPECTIVA PARA O SÂNSCRITO}

William Jones Surge no cenário linguístico, profundo conhecedor das línguas orientais, no ano de 1786, apresentou a Royal Asiatic Society de Calcutá uma comunicação em que demonstrava a existência de uma língua ancestral do Sânscrito, Latim e Grego. Essa comunicação marcou o início dos estudos da linguística comparada e da linguística indo-europeia, historicamente falando. A Asiatic Society, criada por Jones, publicou em torno de 12 volumes, os quais constituem os primeiros estudos acerca do indo-europeu.

Os estudos acerca do Sânscrito, do Grego, do Latim do Gótico e do Céltico iniciam as pesquisas indo-europeias. Essa língua passou a ser analisada com profundidade porque os hindus se preocupavam com a pureza da língua, daí não podia se contaminar. Isso fez com que formas linguísticas arcaicas se conservassem e facilitassem o confronto de raízes vocabulares com a de outras línguas mais antigas.

Esse cuidado dos indianos com a sua língua proporcionou aos europeus comparar com o Grego e com o Latim vários aspectos das formas arcaicas e a partir destas a reconstrução da forma primeira, da forma primitiva. Diante disse, os pesquisadores europeus puderam analisar as formas divergentes entre o Sânscrito, o Latim e o Grego. Assim, o genitivo da palavra gênero, significa em Latim generis, em Grego geneos e em Sânscrito janasas. (PERINI,1997, pp,71/72)

As palavras supracitadas das três línguas clássicas fizeram com que os teóricos europeus percebessem a permanência do $S$. A conservação do $\mathrm{S}$ no final da palavra no Sânscrito levou reconstrução da forma primitiva e a 
construção de uma lei fonética para explicar as formas latina e grega em confronto com a língua sagrada dos Vedas. Uma característica herdada do indo europeu pelo Sânscrito foi o consonantismo arcaico.

O consonantismo na língua sagrada da índia refere-se às aspiradas $b h, d h$ e $g h$, que passaram para o latim como espirantes $(f, h)$ ou se confundiram com as nãoaspiradas: $b, d, g$; o $\mathrm{S}$ intervocálico também permaneceu como na palavra jana-s-as, mas no latim se transforma em R. No grego desapareceu. Manteve o $i$ consoante, porém no Latim e no Grego pode desaparecer.

\section{OS NOMES NO SÂNSCRITO}

Assim como o Latim e o Grego, o Sânscrito guarda semelhança no que se refere aos casos. Além dos seis casos presentes nessas línguas, o Sânscrito ainda possuía mais dois da língua primitiva: $o$ instrumental, o qual indica o meio e o agente e o vocativo. No latim, o instrumental se fundiu com o ablativo (função sintática de adjunto adverbial), porém guarda alguns resquícios; em certas situações aparecem. Já no Grego, se fundiram com o dativo. E o ablativo desapareceu.

Apresentamos abaixo um quadro para ilustrar o parágrafo aludido acima, com a declinação da palavra "deus", em todos os casos, no singular e no plural.

\begin{tabular}{|c|c|c|c|}
\hline & $\begin{array}{l}\text { Singu } \\
\text { lar }\end{array}$ & Dual & Plural \\
\hline $\begin{array}{l}\text { Nomina } \\
\text { tivo }\end{array}$ & $\begin{array}{l}\text { Deva } \\
-s\end{array}$ & Devau & Devas \\
\hline $\begin{array}{l}\text { Vocativ } \\
\text { o }\end{array}$ & Deva & Devau & Devas \\
\hline $\begin{array}{l}\text { Acusati } \\
\text { vo }\end{array}$ & $\begin{array}{l}\text { Deva } \\
\mathrm{m}\end{array}$ & & devan \\
\hline $\begin{array}{l}\text { Instrum } \\
\text { ental }\end{array}$ & $\begin{array}{l}\text { Deve } \\
\text { na }\end{array}$ & Devabhyam & devais \\
\hline Dativo & $\begin{array}{l}\text { Deva } \\
\text { ya }\end{array}$ & Devabhyam & $\begin{array}{l}\text { Deve- } \\
\text { bhyas }\end{array}$ \\
\hline $\begin{array}{l}\text { Ablativ } \\
\text { o }\end{array}$ & $\begin{array}{l}\text { Deva } \\
\mathrm{t}\end{array}$ & Devabhyam & $\begin{array}{l}\text { Deve- } \\
\text { bhyas }\end{array}$ \\
\hline $\begin{array}{l}\text { Genitiv } \\
\mathrm{O}\end{array}$ & $\begin{array}{l}\text { Deva } \\
\text { sya }\end{array}$ & Devayas & $\begin{array}{l}\text { Devan } \\
\text { yam }\end{array}$ \\
\hline $\begin{array}{l}\text { Locativ } \\
\text { o }\end{array}$ & Deve & & $\begin{array}{l}\text { Deves } \\
\mathrm{u}\end{array}$ \\
\hline
\end{tabular}

\section{OS VERBOS NO SÂNSCRITO}

No Sânscrito, o verbo se caracteriza por possuir voz ativa e media. As desinências pessoais se referem aos três gêneros. Uma outra característica do verbo é a presença de tema, em que o presente, o perfeito, o aoristo e o futuro têm. Os modos verbais são três: indicativo, optativo e imperativo. No védico, também há o conjuntivo. O tema temporal tem seu particípio. O particípio aoristo acontece no 
védico. Há três formas nominais: infinitivo, gerúndio e o gerundivo.

Também a raiz verbal origina temas especiais como forma de conseguir o verbo no passivo, causativo, este o sujeito faz a ação expressa pela raiz. Assim pela raiz tud 'bater', se origina o causativo tod-aya-ti, faz 'bater'. O intensivo - indicando repetição com intensidade da ação - e o desiderativo, o qual indica desejo de cumprir a ação. O tema do presente tanto pode surgir da raiz pura, na qual se acrescenta desinências pessoais, como por exemplo: as-mi: 'sou'; e-mi 'vou'; ai surge a reduplicação, da-dá-mi;'dou' .

No Grego, 'di-do-mi’ - , das raízes $a s-i-d a$, união da raiz com vários sufixos, como -a- (tud-a-ti) 'ele bate', -ya- (div-ya$t i$ 'ele joga', raiz div), -no- ou -nu- (ci-no-ti 'ele amontoa', ci-nu-mas ' nós amontoamos', da raiz ci); -na- ou -ni- (kri$n a-t i$ ' ele vende', kri-ni-mas ' nós vendemos', da raiz kri). O perfeito também é reduplicado (ta-tras- $a$, 'espamtei-me', raiz tras. $\mathrm{O}$ aoristo tem um aumento e o radical puro ( $a$-bhu $t$, 'ele foi', raiz $b h u$ ) ou pode ser formado com o sufixo $-a$ - ( $a$ - vid$a-t$, ' ele achou', raiz vid-). Pode ser reduplicado -at-(a-pa-pt-a-t,'cai',da raiz pat- ou pode ser sintagmático (a-cchout-sam, 'cortei, raiz chid). Já o futuro tem um sufixo-sya- (pat-sya-ti, 'cairá').
CONJUGAÇÃO DE UM VERBO NO PRESENTE DO INDICATIVO ATIVO

O verbo tud - 'bater'.

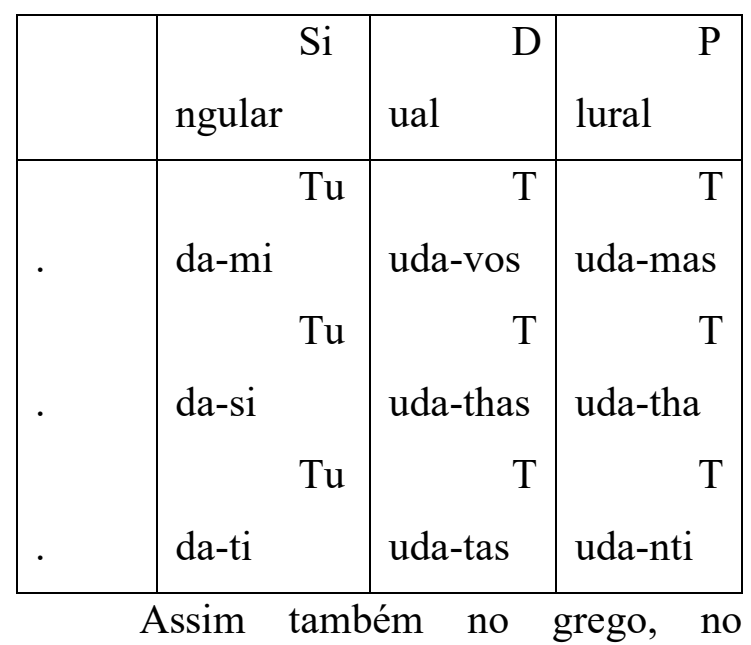

imperfeito, houve o aumento: $a$-tuda-m, $a$ tuda-s, $a-t u-d a-t$ etc. Também no optativo é tudey-am,tude-s,tude- $t \mathrm{e}$ assim por diante. $\mathrm{O}$ particípio é tudant- (nominativo Tudan-, acusativo tudant-am etc.)

Diante do exposto, chega-se à ilação de que a semelhança entre o Latim, o Grego e o Sânscrito é muito evidente. Devido a isso, os primeiros estudiosos da língua hindu associaram-nas as duas línguas clássicas: Latim e Grego (TERRA, 2001, p. $51)$.

\section{OS ALEMÃES: BREVE RELATO DE SEUS ESTUDOS}

FREDERICO VON SCHLEGEL (17721829) (Frederico Schlegel)

Em meios a tantas obras acerca do Sânscrito e a comparação desta com as duas línguas clássicas europeias: o Grego e o Latim e, sem levar em conta os resultados anteriores dos missionários jesuítas 
franceses; Schlegel lançou sua principal obra no campo da comparação: Uber die Sprache und Weisheit der Indier (Sobre a língua e a sabedoria dos hindus). Ein Beitrag zur Begründrung der Alterthumskunde, Heidelberg, 1808.

Além dessas línguas aludidas, o autor ainda incluiu nessa obra o germânico e o persa. Porém, deixou de fora da obra o Armênio, o Eslavo e o Céltico, pois, segundo ele, essas três línguas não mantinham uma relação contígua com as principais línguas estudadas. Schlegel desenvolveu o conceito de parentesco baseado nos traços morfológicos em comuns entre duas línguas ou mais que têm em comum (TERRA, 2001, p. 51).

A base para a constatação dessa semelhança das línguas sânscrita, grega, latina, persa e a germânica foi a morfologia ou estrutura gramatical que possibilitou a criação do critério de analogia das línguas indo-europeias. A criação do critério de parentesco fez os estudos comparativos evoluírem.

Assim, diante da constatação, afirma-se que a identidade verbal dessas línguas antigas ocorrem na primeira pessoa do singular no sânscrita; $m i$-; do grego:mi-; e do persa:- $m$; da terceira pessoa do singular do sânscrito: -ti-; do latim: -t-; do alemão: $t-$; do persa: -t- etc." Schlegel cometeu um equívoco, quando atribuiu ao Sânscrito como a língua-europeia mais antiga e origem de todas as línguas indo-europeias. (TERRA, 2001, p. 56).

\section{AUGUST VON FRIEDRICH (Augusto Friedrich) (1802-1887)}

Professor de Sânscrito na Universidade de Bonn; junto com o seu discípulo, Christian Lassen, criou a cátedra de filologia sânscrita na Europa; bem como a criação do estudo filológico do sânscrito. Isso aprofundou as pesquisas relacionadas aos hinos hindus dos Vedas; o estudo das epopeias hindus: e a Mahabharata e a Rayamana, obra dramática da literatura hindu. Todas essas pesquisas ampliaram o conhecimento filológico do sânscrito.

O foco deste autor foi o léxico. Em 1833-1836, lançou sua obra relacionada à Investigação etimológica no domínio das línguas indo-germânicas em que consistia observar as transformações fonéticas no Sânscrito, no Grego, no Latim, no Lituano e no Gótico. Este trabalho, voltado para o vocabulário das línguas indo-europeias, é o resultado de pesquisas anteriores. Ainda traz um apêndice de estudos morfológicos da linguística comparativa indo-europeia.

\section{AUGUST SCHELEICHER (1821-1868)}

Botânico de formação. Scheleicher aplicou os métodos das ciências da natureza aos estudos da linguagem. Este pesquisador empregou a teoria evolucionista aos estudos históricos comparativos das línguas. Em 
comparação aos organismos vivos, ele afirma que as línguas nascem, crescem, geram, envelhecem e morrem. Scheleicher criou uma fábula em indo-europeu, a qual foi reescrita por muitos outros teóricos. Ele foi o primeiro a estudar a língua indoeuropeia a partir da fala, a língua viva.

$\mathrm{O}$ autor tem como uma de suas primeiras obras: Panorama sistemático das línguas da Europa. Dois anos depois, ele publicou outro trabalho morfologia do eslavo antigo: morfologia da língua eslava eclesiástica, em 1852. Foi o criador da gramática moderna lituana; Manual $d a$ língua lituana, em 1856-1857. A partir de sua obra, desenvolveu a concepção de árvore genealógica (1853).

A concepção de árvore genealógica se encontra nesta obra Compêndio da gramática comparativa do indo-europeu, sânscrito, grego e latim (Compendium der vergleichenden Grammatik der Indogermanischen Sprachen), de 1861. Segundo Robins, (1983, p.144 apud Mendonça 2016), esse trabalho é a junção de várias pesquisas com uma sistematização do que já se tinha descoberto em linguística até aquela época.

A classificação de árvore genealógica deveu-se ao trabalho de comparação do proto - indoeuropeu (língua hipotética), com as línguas mais antigas vivas. A comparação possibilitou Scheleicher a representar as línguas no formato de árvore. Ainda se emprega o formato de árvore atualmente. Mesmo sofrendo críticas, esse modelo de árvore não aponta os meios em que as línguas sofrem mudanças, nem em qual momento originou outra língua. Também não deu conta dos dialetos presentes na língua. Uma língua é composta de dialetos, pois é a força criadora da língua.

Scheleicher criou uma classificação para as línguas do mundo, as quais se dividiam em: isolantes, estas não são decompostas em unidades menores para análise, é o caso do Chinês, do Anamês, do Siamês e do Burmês, línguas monossílabas, na concepção do pesquisador, elas estão em um estágio inferior porque só possuem radicais, não conseguem unir afixos à sua base. Exemplo das línguas nessa questão, as línguas indo-europeias escreveriam assim: "ai-mi (eu vou) seria teoricamente dito como i ou i ma."

As línguas aglutinantes como o Finlandês, o Tatar, o Dekhan e o Basco, que estão acima das isolantes, acrescentam ao radical os afixos. Neste período, as línguas aglutinantes Schleicher, 'o indo-europeu expressaria ai-mi como i-ma ou i-mi.' Por último, as flexionantes, como as indoeuropeias e semíticas, as quais um afixo possui vários significados.

Como a língua é um organismo vivo, para Scheleicher, as línguas possuem dois estágios: pré-histórico, momento em 
que a língua se encontra no estágio isolante, seu ponto de partida até as flexionantes, que é a etapa de desenvolvimento. E período histórico, em que as línguas, depois de atingir todas as etapas, já entram em declínio, fenecem e morrem.

A obra Die Darwinsche Theorie und Sprachwissenschaft (A teoria darwinista e a linguística) publicada em1863, foi enviada para Ernst Haeckel, na qual contesta a teoria evolucionista de Darwin por não apresentar dados empíricos da Teoria da Evolução. E que a teoria Stammbaumtheorie, contribuiria com a Biologia para elucidar casos inexplicáveis da teoria de Darwin, pois as línguas como organismos vivos "serviriam como fósseis" (TERRA, 2001, p.52).

Em 1864, Scheleicher publicou outra obra, desta vez foi sobre biologia: Die Darwinsche Theorie und die Thier- und Pflanzensucht (A teoria darwinista e a pesquisa sobre animais e plantas), e a envia para Charles Darvin. Uma outra criação de Scheleicher foi o uso do asterisco nas formas hipotéticas, emprego que na época ainda não era utilizada, mas que hoje ainda se emprega.

O século XIX, particularmente na metade, foi o apogeu da ciência no campo da evolução. Charles Darwin influenciou toda uma geração de cientistas com sua obra. Biologia e linguística, ambas se complementavam nesse período. Darwin incorporou a teoria da evolução aos estudos linguísticos. Para ele, a pesquisa e a linguagem eram indissociáveis, pois, a linguagem era o principal elemento que diferenciava o homem dos animais. Citara a relação no que se refere à linguagem e à evolução da espécie humana era um grande mistério.

A Alemanha vivia o auge da filosofia do romantismo, movimento em que estava atrelada a natureza. $\mathrm{Na}$ visão deste pensamento, homem e natureza são inseparáveis. Essa filosofia também é conhecida por monismo corrente contrária ao dualismo. Destarte, Scheleicher concebia a evolução da linguagem como a evolução do organismo. Corpo e mente um elemento só. (MARTELOTA,2010)

\section{RASMUS CHRISTIAN RASK (1787- 1832) - dinamarquês}

Rasmus Christian Rask foi relegado ao esquecimento, pois a publicação que realizou foi no dinamarquês. Não ecoou no mundo científico o seu lançamento, pois a língua da ciência na época era o alemão. Isso favoreceu a Franz Bopp, o qual publicou sua obra nessa língua anos depois. Rask dedicou-se a estudar a língua mais antiga da Escandinávia, islandês e a partir desse estudo criou a primeira gramática moderna do islandês. Rask escreveu, em 1814, a obra: Investigação da origem do antigo escandinavo e do islandês, em que 
relacionava o antigo norueguês com o germânico, o gótico e as línguas eslavas. (BAGNO, 2011, pp. 53-54)

Rask pesquisou várias línguas europeias na busca de encontrar vestígios de afinidade com o indo-europeu. Ele focou sua análise nas línguas germânicas, primeiramente, no gótico por ser mais antiga e extinta, sua existência se deu por fragmentos bíblicos, por volta do século IV, cuja tradução fora feita por Ulfila. $\mathrm{Na}$ sequência, aparecem as línguas germânicas 'ocidentais', o Alemão, o Inglês e o Groenladês. Também incluiu nesse seu trabalho o Céltico, o Eslavo, o Báltico e o grupo 'trácio', composto pelo Grego e pelo Latim.

Uma das regras criadas por Rask foi de que o parentesco de várias línguas devese confirmar muito mais pelo confronto morfológico do que pelo lexical. O lexical sofre influência de empréstimo ou mistura de culturas de povos vizinhos. Com a comparação gramatical de várias línguas torna-se mais forte o parentesco ou a origem comum delas.

Coube a Rask o pioneirismo na criação da gramática comparada ao confrontar fonemas das línguas: Grego, Latim, Báltico, Eslavo e Islandês. Esse estudo estabeleceu o parentesco dessas línguas. Se, por exemplo, no grego e no latim tem um - $p$ - no início; nas línguas germânicas aparecem um -f-:grego Patér, latim Páter; gótico fadar; latim piscis; gótico Fisks ; grego Polús; gótico gótico Filu; o-T-grego e latim, no gótico aparece th, latim $t u$, gótico $T h u$; grego treis, latim três, gótico Threis, latim tacere, gótico Thahan.

\section{FRANZ BOPP}

O processo de comparar as línguas se deu quando os primeiros europeus descobriram o Sânscrito, língua sagrada dos hindus. A partir dessa descoberta chegaram à ilação que as línguas podiam conter semelhanças entre si, dentre elas como mais antigas: o Sânscrito, o Latim, o Grego, o Germânico e o persa. Mas os estudos comparativos se iniciaram com Schlegel, quando publicou o seu trabalho sobre o parentesco das línguas antigas.

O trabalho de Schlegel mostrou que as línguas antigas provinham do sânscrito, fato este corrigido por Franz Bopp, quando publicou seu trabalho: "Sobre o sistema de conjugação da língua sânscrita em comparação com a língua grega, latina, persa e germânica," apontando o erro de Schlegel ao atribuir ao sânscrito como “mãe” das outras línguas antigas.

Em seu trabalho, Bopp analisou de forma minuciosa a morfologia verbal das línguas antigas em estudo e a correspondência que havia entre elas, com isso Bopp ganhou relevância porque demonstrou por meio da comparação o 
parentesco das línguas supracitadas. Bopp, no entanto, não observou a sequência histórica das mudanças fonéticas, cabendo a Jacob Grimm a responsabilidade de o incluir a sequência histórica. (CAROLINE,2015, p,39)

Bopp observou as formações do presente do indicativo do Sânscrito e do Grego, como a vogal temática, a reduplicação do presente dos verbos em $m i$, em Grego e em Sânscrito; o sufixo -nu- do presente em grego e em Sânscrito; o sufixo -ne- em Grego e -na- em Sânscrito; o aumento do imperfeito e a reduplicação do perfeito e a formação sintagmática.

Assim, Franz Bopp passou para o mundo da ciência como o criador da gramática comparada das línguas europeias. Este cientista ao desenvolver o método comparativo influenciou no desenvolvimento do método histórico comparativo relacionado às línguas neolatinas. Um grande avanço para a ciência da época, pois foi a partir dessa abordagem que originou os estudos linguísticos.

\section{O NASCIMENTO DA FILOLOGIA ROMÂNICA}

A Filologia Românica se constituiu como ciência a partir dos estudos comparativos de Franz Bopp, em 1816, com o livro Sobre o Sistema de Conjugação do Sânscrito em Comparação com o Grego, com o Latim, com o Persa e com o Germânico. A publicação desse trabalho deu origem aos estudos científicos linguísticos, na Europa, por meio do método histórico-comparativo ao confrontar estrutural gramatical.

A comparação criou o "parentesco das línguas". Com o parentesco surgiu a classificação genealógica dos idiomas mais antigos, que é a reconstrução das formas mais antigas das línguas, o qual remonta ao passado mais distante dos idiomas como o Latim, o Eslavo e o Germânico (ILARI,1992, p. 18)

Frederich Diez, linguista alemão, aplicou o método histórico-comparativo desenvolvido por Franz Bopp às línguas neolatinas. Diez primeiramente abordou, em seus escritos, obras castelhanas antigas; em seguida analisou o provençal e no percurso desse seu trabalho incorporou outras línguas românicas. A pesquisa rendeu a Diez, três volumes de sua Gramática das línguas românicas (1836); e o Dicionário etimológico das línguas românicas (1853). (ILARI, 1992, p. 17)

Frederich Diez provou, por meio do método histórico comparativo, que o latim e as línguas românicas possuem um tronco comum, assim como a relação do indoeuropeu com o Grego, o Sânscrito, o Latim e o Germânico. O linguista alemão apontou em sua gramática que todas as línguas latinas são provenientes do latim vulgar, 
modalidade linguística usada por toda uma população que não fez parte da elite romana (BASSETO,2001, p. 32).

Os dois trabalhos de Diez supracitados originaram os estudos filológicos em relação às línguas neolatinas e a criação de uma ciência exclusivamente para estudar as línguas derivadas do Latim. A disciplina compara a forma que a palavra foi no Latim e a sua forma atual. Daí a denominação de Filologia românica, ciência que se ocupa do latim e suas descentes, pois foi empregado para estudalas. (ILARI, IBIDEM)

\section{FERDINAND SAUSSURE}

Ferdinand Saussure, professor de Sânscrito e comparatista, transformou um conhecimento antigo em uma ciência, mas isso não aconteceu como passe de mágica. Foram anos de estudos e publicações como estão no corpo do texto acima, até atingir um acúmulo de informações e conhecimento de forma, que deu a Saussure os instrumentos necessários para a criação de uma nova ciência da linguagem. E a primazia de ser o criador da ciência da linguagem - Linguística. (BRANDÃO e VITORINO,2015)

\section{CONCLUSÃO}

O trabalho dos hindus se reveste de relevância, porque foi a partir deles que se constituiu e construiu a Linguística como
O mestre genebrino ao criar a nova ciência deu-lhe um objeto de estudo: a língua. Criou as leis que regeram a ciência dando, assim ao estudo da língua, o nome de Linguística. Ciência que estuda a linguagem humana escrita ou falada. Uma das primeiras foi a distinção entre língua (langue) e fala (parole). A primeira é social e a segunda individual. O segundo elemento foi a criação do signo linguístico, que se divide em significante e significado. Saussure desenvolveu o conceito de dicotomia (FIORIN, p. 28).

Os conceitos foram: Significado é o conceito, é a imagem acústica. Significante se realiza nos fonemas e nas letras. Uma outra divisão da língua proposta por Saussure: sintagma e paradigma. O sintagma é a realização de formas mínimas numa unidade linguística superior. Paradigma se constitui de elementos semelhantes, os quais estão na memória. Em seguida cita sincronia e diacronia. A sincronia é o estudo descritivo da língua, num estágio atual. A diacronia é a abordagem histórica da língua (FIORIN, pp.55/6/7/8/63).

ciência. Primeiro a comparação com as línguas mais antigas: Sânscrito, latim, Grego, Germânico e Eslavos. Essas línguas possibilitaram a criação de um método. 
$\mathrm{O}$ método comparava vocábulos e raízes das línguas supracitadas até chegarem à ilação que elas tiveram uma origem comum. A origem comum foi denominada de Língua Indo-Europeia devida à semelhança das raízes dessas línguas clássicas.

Os profissionais que realizaram essa tarefa de comparar foram os linguistas comparatistas. Um dos linguistas comparatistas e professor de Sânscrito foi Saussure, que observou e construiu o objeto

\section{REFERÊNCIAS}

BASSETO, Bruno Fregni. Elementos de filologia românica.São Paulo:EDUSP, 2005

BAGNO, Marcos. Gramática pedagógica do português. brasileiro.São Paulo: Parábola, 2011.

BENVEnISTE, Émile. Problemas de linguística geral. V.2. Campinas: Pontes: 1989.

Brandão, Jacyntho Lins; Vitorino, Júlio César. O método histórico-comparativo. Faculdade de Letras da UFMG Fundamentos de Linguística ComparadaApostila. Disponível em: https://grad.letras.ufmg.br/arquivos/monito ria/Aula3 lingcomp_apostila_texto4.pdf. Acesso em: 11/10/2020.

CAROLINE,Nogueira da Silveira.O CLG como objeto histórico: um estudo das gramáticas.2015. Dissertação (Mestrado) - Universidade Federal doRio Grande do Sul, Instituto de Letras, Programa dePósGraduação em Letras, Porto Alegre, BRRS, 2015.

CHASSOT, Attico. A ciência através dos tempos. São Paulo: Moderna, 2004. de uma nova ciência: a Linguística. Saussure ao criar uma nova ciência abriu as portas do mundo da ciência para o estudo da linguagem.

Este estudo, apresentou o Sânscrito portanto, como base para o surgimento da gramática e da linguística, daí a importância do profissional de letras reconhecer essas informações, considerá-las e retirar das mesmas as maiores contribuições possíveis para sua prática profissional.

COSERIU, E. Teoria del lenguage $\mathbf{y}$ linguística general: cinco estúdios. Madri: Biblioteca Românica Hispánica/ Editorial Gredos, 1973.

FARACO, Carlos Alberto. Gra mática e ensino. Rio de Janeiro, Diadorim, v.19, n.2, pp.11-26, Jul./Dez., 2017.

FIORIN, J. L. As astúcias da enunciação: as categorias de pessoa, espaço e tempo. São Paulo: Ática,2001

São Paulo: Contexto,2013

Linguística? Que é isso?

ILARI, Rodolfo. Lingüística românica. São Paulo: Ática, 1992.

LYONS, John. Introdução à linguística teórica. São Paulo: Nacional, 1979, pp.154.

MARTELOTA, Mário Eduardo(org). Manual de linguística. 1. ed., $3^{\mathrm{a}}$ reimpressão. São Paulo Contexto,2010.

MARCUSCHI, Luiz Antônio. Produção textual, análise de gêneros e compreensão. São Paulo: Parábola Editorial, 2008. 
MOUNIN, G. s.d. História da linguística: das origens ao século XX. [1970] Porto: Despertar.

MIAZZI, Maria Luísa Fernandez. Introdução à linguística românica. S. Paulo: Cultrix, 1976. (MIA)

NEVES, Maria Helena de Moura. A vertente grega da gramática tradicional. São Paulo. Hucitec; Editora Universidade de Brasília. 1987.

PERINI, Mário A. Sofrendo a gramática. São Paulo: editora ática, 1997.

PETTER, Margarida. Linguagem, língua, linguística. In FIORIN, José Luiz (org.). Introdução à Linguística I - Objetos Teóricos. São Paulo: Contexto, 2010

ROBINS, Robert Henry. Pequena história da linguística. Rio de Janeiro: Ao Livro técnico, 1983.
SILVA, Francisco Borges da. Contribuições lingüísticas: dos estudos saussurianos aos estudos modernos. Disponível em: http://saber.unioeste.br/index.php/travessia s/article/viewFile/3047/2392. Acesso em: 11/10/2020.

SILVA, Jucélia Araújo da. Análise de abordagem gramatical em manuais de ELE.

Dissertação (Mestrado) - Universidade Federal de Pernambuco. Centro de Artes e Comunicação. Programa de Pós-Graduação em Letras, Recife. 2019.

WEEDWOOD, Barbara. História concisa da linguística. São Paulo: Parábola, 2002.

VIARO, Mário Eduardo. "A língua do Paraíso". In Língua Portuguesa, ano 8, $\mathrm{n}^{\circ}$ 89, março, 2013.

STELLA, Jorge Bertolaso. A língua sânscrita e a cultura. Disponível em: revista.ufpr.br. Acesso em: 05/06/2020. 